\title{
VOLTAMMETRIC BEHAVIOR OF SOME STEELS IN AQUEOUS SOLUTIONS OF $\mathrm{HNO}_{3}$
}

\author{
Gheorghe Nemtoi ${ }^{1}$, Liliana Airinei ${ }^{2}$, Tudor Lupascu ${ }^{3}$ and Alexandru Cecal ${ }^{1 *}$ \\ 1 “Al. I. Cuza” University, Faculty of Chemistry, 11-Carol I Bvd., 700506 - Iasi, Romania \\ 2 Technical College “Gheorghe Cartianu”, Traian Bvd., 610143, Piatra-Neamt, Romania \\ ${ }^{3}$ Institute of Chemistry, Academy of Sciences of Moldova, Republic of Moldova \\ *Email: cecal@uaic.ro
}

\begin{abstract}
The corrosion process of some steels immersed in $\mathrm{HNO}_{3}$ solutions of different concentrations by means of voltammetric measurements was investigated. Even if the differences regarding the chemical composition of these steels were relatively low, it was succeeded to establish some electrochemical parameters $\left(\mathrm{R}_{\mathrm{p}}, \mathrm{E}_{\mathrm{corr}}, \mathrm{E}_{\mathrm{pc}, \mathrm{pc}}, \mathrm{E}_{\mathrm{F}}, \mathrm{I}_{\mathrm{pas}}, \mathrm{E}_{\mathrm{str}}\right.$ and $\mathrm{D}_{\text {pas }}$ ) with different values, in several experimental conditions. For different values of the corrosion potential, or of the contact time solid steel-aggressive medium, were proposed equations of the type: $I=f(E)$, only for linear domains from the given voltammograms.
\end{abstract}

Keywords: corrosion, electrochemical parameters, nitric acid, steels, voltammograms,

\section{Introduction}

Studies on the global process of corrosion were published by several authors both in monographs and in detailed articles [1-7]. There are also scientific papers which deal only with certain aspects of the corrosion process. Thus, Caceres et al. [8] determined the electrochemical parameters and the corrosion rate of carbon steel in $\mathrm{NaCl}$ buffered solution, while Sing and Mukherjee [9] dealt with the kinetics of acid dissolution of some mild steels. Nemtoi et al. [10-14] characterized the electrochemical behavior of some steels or non-ferrous alloys in electrolyte medium, under different experimental conditions. Moraru et al. [15] investigated corrosion kinetics of the $\mathrm{G} 105$ and P105 steels in $3 \% \mathrm{NaCl}$ and $\mathrm{KCl}$ solutions establishing that the anodic dissolution of iron is described by the exponential equations characteristic to the first order chemical reactions. Moreover there are developed some electrochemical techniques combined with the use of radionuclides, Möessbaer spectroscopy, electronic microscopy, or uv-vis spectrophotometry etc, for the elucidation of the corrosion processes [16-23]

This paper presents an electrochemical study on the corrosion of seven different steels immersed into $\mathrm{HNO}_{3}$ solutions of different concentrations, pointing out certain parameters that describe the corrosion process in several experimental conditions.

\section{Materials and equipment}

The chemical composition of the steels used in the present paper is shown in table 1, the iron content being in the domain $97.772-98.782 \% \mathrm{~g}$.

Chemical composition of the studied steels (\% gr)

\begin{tabular}{|c|c|c|c|c|c|c|c|c|c|c|c|}
\hline $\begin{array}{c}\text { Steel } \\
\text { sample }\end{array}$ & $\mathrm{C}$ & $\mathrm{Si}$ & $\mathrm{Mn}$ & $\mathrm{P}$ & $\mathrm{S}$ & $\mathrm{Cr}$ & $\mathrm{Mo}$ & $\mathrm{Ni}$ & $\mathrm{Al}$ & $\mathrm{Cu}$ & $\mathrm{V}$ \\
\hline 2 & 0.190 & 0.210 & 0.610 & 0.021 & 0.008 & 0.050 & 0.020 & 0.030 & 0.036 & 0.040 & 0.003 \\
\hline 3 & 0.310 & 0.220 & 0.730 & 0.009 & 0.006 & 0.610 & 0.210 & 0.030 & 0.026 & 0.070 & 0.007 \\
\hline 5 & 0.140 & 0.230 & 0.630 & 0.010 & 0.004 & 0.090 & 0.020 & 0.070 & 0.025 & 0.170 & - \\
\hline 6 & 0.370 & 0.260 & 1.090 & 0.012 & 0.019 & 0.60 & 0.040 & 0.120 & 0.004 & 0.180 & 0.005 \\
\hline 7 & 0.320 & 0.200 & 0.710 & 0.010 & 0.012 & 0.540 & 0.190 & 0.040 & 0.025 & 0.140 & 0.005 \\
\hline 11 & 0.170 & 0.240 & 0.810 & 0.020 & 0.014 & 0.040 & 0.010 & 0.020 & 0.035 & 0.030 & 0.006 \\
\hline 15 & 0.190 & 0.230 & 0.630 & 0.013 & 0.009 & 0.140 & 0.020 & 0.050 & 0.030 & 0.080 & 0.003 \\
\hline
\end{tabular}

The experimental data obtained by linear polarization were afterwards processed by the Stern method, [24] using in all the cases the same values of the potential interval $\left(\mathrm{E}_{\text {corr }} \pm 15 \mathrm{mV}\right)$ to calculate the polarization resistance $\mathrm{R}_{\mathrm{p}}$.

Supplementary details on the processes that take place in the system may be obtained from analyzing the linear polarization curves on extended potential domains when it it it?) defines a critical polarization point [25]. This point corresponds to the maximum preceding the passivation process, passivity potential and current, passivation domain and penetration potential $\mathrm{E}_{\text {str }}$ - corresponding to the end of the passivation domain. These dimensions are pointed out for aqueous solutions of $\mathrm{HNO}_{3}$, of 0.4 and $4 \mathrm{M}$, while for the $0.04 \mathrm{M}$ solutions, over the whole or part of the potential domain, where appears a slight monotonous increase of the current (it is not clear). In order to modify the potential, we started 
from a sufficiently high negative potential to reduce all the ionic or molecular species that impurified the alloy surface. The variation rate of the working electrode potential has been relatively high $(10 \mathrm{mV} / \mathrm{s})$ to obtain current intensities that be sufficiently to cover the possible accidental system fluctuations, yet sufficiently low to sense all the processes that take place in the solution or on the electrode surface.

For experiments the AutoLab PG STAT 302N Potentiostat (Olanda-Eco Chemie) was used coupled with a GPES software for data processing and interpretation, to determine the open circuit potential (OCP) and for performing the polarization studies. The potentiodynamic anodic polarization tests were performed in nitric acid solutions with 0.04 ; 0.4 and $4 \mathrm{M}$ concentrations.

All potentiodynamic polarization experiments were performed at room temperature using an electrochemical cell with three electrodes. The reference electrode was the saturated calomel electrode (SCE) and as an auxiliary electrode a platinium wire (Pt) was used. The working electrode, achieved for each steel sample mentioned in table 1, processed in cylindrical form with a diameter of $5 \mathrm{~mm}$ embedded into a polymer matrix with $11 \mathrm{~mm}$ diameter, so that the part exposed to corrosion was a circular surface, without edges or corners. Before the experimental determinations the working electrodes were mechanically polished with $\mathrm{SiC}$ abrasive paper (120 - 2000 gradually) and aluminium paste of $1 \mu \mathrm{m}$ granulation, after which they were washed with water and degreased with ethanol. Before being used in the electrochemical cell, the electrodes were kept in distilled water where a ten minutes nitrogen flow was bubbled to remove oxygen.

\section{Results and discussions}

In aqueous solutions of $\mathrm{HNO}_{3}$ the corrosion potential of metals is attributed to the main "electroactive" species, $\mathrm{HNO}_{2}$ which is implied in the self-catalytic reactions [26-29].

In the anodic dissolution of iron and its alloys, an important role is played by the water molecules and the anions adsorbed on the metal surface, as a result, Sato [30] proposes the following simplified mechanism:

$$
\begin{aligned}
& \mathrm{Fe}+\mathrm{H}_{2} \mathrm{O} \rightarrow \mathrm{Fe}(\mathrm{OH})_{a d s}+\mathrm{H}^{+}+e^{-} \\
& \mathrm{Fe}(\mathrm{OH})_{a d s} \rightarrow \mathrm{FeOH}{ }^{+}+e^{-} \\
& \mathrm{FeOH}{ }^{+} \rightarrow \mathrm{Fe}^{2+}+\mathrm{HO}^{-}
\end{aligned}
$$

The corrosion mechanisms of steels in nitric acid should take into account the concentration and the factors that promote trans-passive corrosion by increasing the corrosion potential [31-32]. The appearance of some nitrous acid "electroactive" species by self-catalytic reduction of $\mathrm{HNO}_{3}$ can be explained due to $\mathrm{NO}_{2}$ output. Depending on the nitric acid concentration, the temperature and the implied reduction agent, the final corrosion products may be different.

In case of higher concentrations of nitric acid $\left(>8 \mathrm{M} \mathrm{HNO}_{3}\right.$ ) or at higher temperatures, the main heterogonous chemical reaction is the self-catalytic reduction of nitric acid to nitrous acid and $\mathrm{NO}_{2}$ which accumulates in aqueous medium :

$$
\begin{aligned}
& 4 \mathrm{HNO}_{3} \rightarrow 2 \mathrm{H}_{2} \mathrm{O}+4 \mathrm{NO}_{2}+\mathrm{O}_{2} \\
& \mathrm{NO}_{2}+e^{-} \rightarrow \mathrm{NO}_{2}^{-} \\
& \mathrm{NO}_{2}^{-}+\mathrm{H}^{+} \rightarrow \mathrm{HNO}_{2} \\
& \mathrm{HNO}_{2}+\mathrm{HNO}_{3} \rightarrow 2 \mathrm{NO}_{2}+\mathrm{H}_{2} \mathrm{O}
\end{aligned}
$$

In the case of lower temperatures and concentrations, the reduction of nitrous acid is the main electrochemical reaction and the final product is $\mathrm{NO}$ :

$$
\begin{aligned}
& 2 \mathrm{HNO}_{3} \rightarrow \mathrm{HNO}_{2}+\mathrm{O}_{2} \\
& \mathrm{HNO}_{2}+\mathrm{H}^{+} \rightarrow \mathrm{NO}^{+}+\mathrm{H}_{2} \mathrm{O} \\
& \mathrm{NO}^{+}+e^{-} \rightarrow \mathrm{NO} \\
& \mathrm{NO}+\mathrm{HNO}_{3} \rightarrow \mathrm{HNO}_{2}+\mathrm{NO}_{2}
\end{aligned}
$$

For both the mechanisms, the self-catalytic reduction of nitric acid leads to oxidizers as $\mathrm{NO}, \mathrm{NO}_{2}$ and $\mathrm{HNO}_{2}$. Similarly, the metal dissolution is self-catalytic in nitric acid because the oxidized cations from solution are available for reduction, as such accelerates the metal dissolution. The electrochemical cathodic reduction has proved to take place at smaller concentrations of $\mathrm{HNO}_{3}(\leq 6 \mathrm{M})$ while the reduction mechanism, followed by the "electroactive" species regeneration that lead to the self-catalytic dissolution of the metal, is real at higher concentrations of $\mathrm{HNO}_{3}(11 \mathrm{M})$, if it is referred to the inoxidable austenitic steels. As it noticed in the present paper, during the corrosion process of steels in the aqueous solutions of $\mathrm{HNO}_{3}$ there appear brown-red colored precipitations (as rust) around the metallic samples 
and may assert that in the respective reactant systems, after a certain contact time: steel-aggressive medium, different transformations may take place, as the following sequences show:

$$
\begin{aligned}
& \mathrm{Fe}+2 \mathrm{HNO}_{3} \rightarrow \mathrm{Fe}^{2+}+2 \mathrm{NO}_{2}+2 \mathrm{HO}^{-} \\
& \mathrm{Fe}^{2+}+\mathrm{HO}^{-} \rightarrow \mathrm{FeOH}^{+} \\
& \mathrm{FeOH}+\mathrm{HO}^{-} \rightarrow \mathrm{Fe}(\mathrm{OH})_{2}^{+}+e^{-} \\
& \mathrm{Fe}(\mathrm{OH})_{2}^{+} \rightarrow \gamma \mathrm{FeO}(\mathrm{OH})+\mathrm{H}^{+} \\
& \mathrm{H}^{+}+e^{-} \rightarrow \frac{1}{2} \mathrm{H}_{2} \\
& 3 \mathrm{FeO}(\mathrm{OH})+\frac{1}{2} \mathrm{H}_{2} \rightarrow \mathrm{Fe}_{3} \mathrm{O}_{4}+2 \mathrm{H}_{2} \mathrm{O} \\
& 2 \mathrm{FeO}(\mathrm{OH}) \rightarrow \mathrm{Fe}_{2} \mathrm{O}_{3}+\mathrm{H}_{2} \mathrm{O}
\end{aligned}
$$

The $\mathrm{FeOH}^{+}$and $\mathrm{Fe}(\mathrm{OH})_{2}^{+}$species are intermediaries resulting stable compounds $\mathrm{FeO}(\mathrm{OH}), \mathrm{Fe}_{3} \mathrm{O}_{4}$ and $\mathrm{Fe}_{2} \mathrm{O}_{3}$ fact that will lead to the modification of the respective steel initial structure.

\section{Electrochemical investigations for the study of corrosion}

To study the electrochemical corrosion processes, the potentiodynamic method in the variant of line polarization is frequently used [33-37]. The electrochemical polarization technique represents a rapid way to determine the behavior to corrosion of a metal in a given medium and to evaluate the thermodynamic tendency of this process, by immersing the metal or the alloy into an aggressive solution. The corrosion potential, $\mathrm{E}_{\text {corr }}$ is a measure of the corrosion tendency of a metal or an alloy immersed into a given electrolytic medium, the modification of which may give indications on the active/passive behavior in metals and alloys. The corrosion potential may be determined by means of linear polarization curves, directly from the voltammogram as being the open circuit potential (OCP) or using the Evans diagrams by representing the logarithms of the current density depending on the potential of the electrode on a overpotential of $\pm 50 \div 150 \mathrm{mV}$. In these coordinates, the crossing of the linear parts of the anodic and cathodic branches (as Taffel slopes) of the polarization curve gives, on the potential axis, the values of $\mathrm{E}_{\text {corr }}$.

The method of linear polarization resistance serves to determine the corrosion current at the corrosion potential of an alloy by plotting the polarization curve obtained at relatively low overpotentials. The corrosion current determined by this way represents, in fact, the corrosion current that appears at the interface metal/corrosive medium when this solid sample is immersed into solution and cannot be measured directly by means of electrochemical methods. The method is based on the evaluation of the polarization resistance, $R_{p}$, defined as the tangent slope of the potential curve - the current density $[E=f(j)]$ in the poise $\left(\mathrm{E}=\mathrm{E}_{\mathrm{rev}}\right.$ or overtension $\left.\eta=0\right)$, namely the free corrosion potential:

$$
\mathrm{R}_{\mathrm{p}}=\left[\frac{\Delta \mathrm{E}}{\Delta \mathrm{j}}\right]_{\mathrm{E}=\mathrm{E}_{\mathrm{rev}}},
$$

Here, $j$ is defined by the relation between measured current intensity (I) at an electrode with a given surface (S).

From potentiometric curves plotted in the coordinates $I=f(E)$, for the domain $\mathrm{OPC} \pm 15 \mathrm{mV}$ it was determined the polarization resistance $\mathrm{R}_{\mathrm{p}}$. Such a graphic plot is exemplified below only for sample no.5, yet the values of this parameter are summarized in table 2.

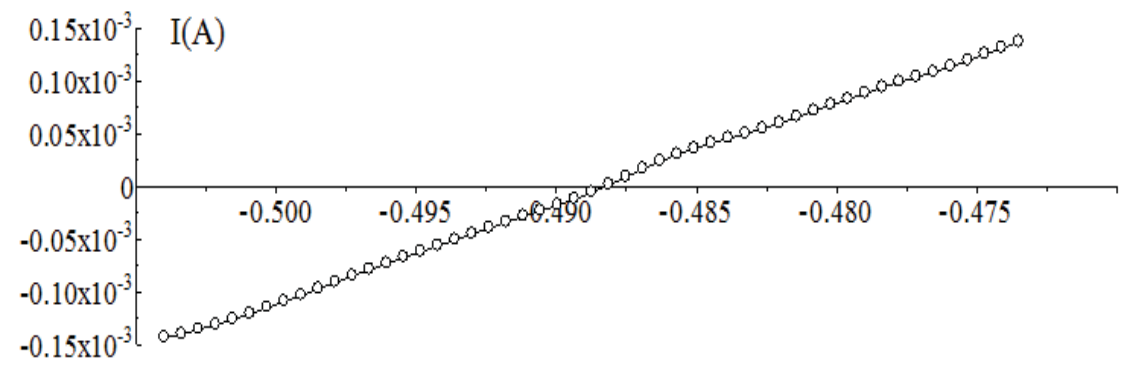

$\mathrm{E}(\mathrm{V})$

Fig. 1. The voltammogram plotted for sample 5 for determining the polarization resistance in aqueous solution $0.04 \mathrm{M} \mathrm{HNO}_{3}$ 
Table 2

Voltammetric parameters obtained by the Tafel slopes method

\begin{tabular}{|c|c|c|c|c|c|c|c|}
\hline $\begin{array}{c}\text { Steel } \\
\text { sample }\end{array}$ & 2 & 3 & 5 & 6 & 7 & 11 & 15 \\
\hline \multicolumn{8}{|c|}{$0.04 \mathrm{M} \mathrm{HNO}_{3}$} \\
\hline$-\mathrm{OPC}(\mathrm{V})$ & 0.506 & 0.498 & 0.461 & 0.445 & 0.488 & 0.543 & 0.480 \\
\hline $\mathrm{R}_{\mathrm{p}}(\Omega)$ & 111.6 & 112.4 & 163.5 & 64.2 & 228.5 & 123.1 & 112.2 \\
\hline \multicolumn{8}{|c|}{$0.4 \mathrm{M} \mathrm{HNO}_{3}$} \\
\hline$-\mathrm{OPC}(\mathrm{V})$ & 0.430 & 0.344 & 0.374 & 0.374 & 0.357 & 0.408 & 0.363 \\
\hline $\mathrm{R}_{\mathrm{p}}(\Omega)$ & 8.34 & 9.51 & 10.76 & 7.63 & 9.82 & 10.26 & 7.917 \\
\hline \multicolumn{7}{|c|}{$4.0 \mathrm{M} \mathrm{HNO}$} \\
\hline$-\mathrm{OPC}(\mathrm{V})$ & 0.309 & 0.264 & 0.296 & 0.257 & 0.270 & 0.301 & 0.288 \\
\hline $\mathrm{R}_{\mathrm{p}}(\Omega)$ & 3.029 & 2.391 & 2.177 & 1.537 & 1.897 & 2.343 & 2.266 \\
\hline
\end{tabular}

The values of potential in the open circuit potential (OCP) were established for all the alloy samples immediately after the immersion of the work electrode into the solution (WE), that indicates the spontaneous formation of passivation film. The open circuit potential is identified with the corrosion potential $\left(\mathrm{E}_{\text {corr }}\right)$ due to the fact that the last is defined as the potential of an electrode measured compared to the control/reference (ER) when the current in the exterior circuit is zero. The transfer of the OCP values to more noble values (reduced) is linked to the more rapid increase of passivation film and this depends on the nature of the formed passive oxide stratum. The $\mathrm{R}_{\mathrm{p}}$ values of all the samples are in the concentrated solution $\left(4 \mathrm{M} \mathrm{HNO}_{3}\right.$ ), a fact that may be due to the generation of several reduction products of the nitrous "electroactive" species that accumulate during the corrosion process. The dissolution will take place with higher speeds at higher concentration due to the self-catalytic metal dissolution .

By means of the potentiodynamic method we traced the linear voltammograms on extended domain of: $-0.6 \div$ $3.0 \mathrm{~V}$ out of which it highlighted the critical polarization potential, $\mathrm{E}_{\mathrm{pc}}$, with the corresponding value of the $\mathrm{I}_{\mathrm{pc}}$ current, the passivation potential or the Flade potential, $\mathrm{E}_{\mathrm{F}}$, the passivation current, $\mathrm{I}_{\mathrm{pas}}$, the penetrating potential, $\mathrm{E}_{\mathrm{str}}$, and the passive domain of each alloy $\left(\mathrm{D}_{\mathrm{pas}}\right)$. These parameters are presented in table 3, characteristics obtained in concentrated solutions of 0.4 and $4 \mathrm{M} \mathrm{HNO}_{3}$.

Table 3

Corrosion parameters obtained from the potentiodynamic method in solutions of 0.4 and $4 \mathrm{M} \mathrm{HNO}_{3}$.

\begin{tabular}{|c|c|c|c|c|c|c|c|}
\hline $\begin{array}{c}\text { Steel } \\
\text { sample }\end{array}$ & $\mathrm{E}_{\text {corr }}(\mathrm{V})$ & $\mathrm{E}_{\mathrm{pc}}(\mathrm{V})$ & $\mathrm{I}_{\mathrm{pc}}(\mathrm{mA})$ & $\mathrm{E}_{\mathrm{F}}(\mathrm{V})$ & $\mathrm{I}_{\mathrm{pas}} \mathrm{mA}$ & $\mathrm{E}_{\text {str }}(\mathrm{V})$ & $\mathrm{D}_{\text {pas }}(\mathrm{V})$ \\
\hline \multicolumn{8}{|c|}{$4 \mathrm{M} \mathrm{HNO}_{3}$} \\
\hline 2 & -0.309 & 0.187 & 63.6 & 0.342 & 2.107 & 1.624 & $0.34-1.62$ \\
\hline 3 & -0.268 & 0.146 & 138.7 & 0.241 & 2.490 & 1.646 & $0.24-1.65$ \\
\hline 5 & -0.300 & 0.413 & 31.8 & 0.653 & 3.723 & 1.534 & $0.65-1.54$ \\
\hline 6 & -0.260 & 0.308 & 73.5 & 0.343 & 2.981 & 1.607 & $0.45-1.59$ \\
\hline 7 & -0.273 & 0.347 & 136.6 & 0.374 & 2.356 & 1.683 & $0.37-1.68$ \\
\hline 11 & -0.303 & 0.305 & 87.4 & 0.327 & 3.105 & 1.623 & $0.49-1.63$ \\
\hline 15 & -0.292 & 0.272 & 78.28 & 0.355 & 1.273 & 1.678 & $0.35-1.68$ \\
\hline \multicolumn{7}{|c|}{$0.4 \mathrm{M} \mathrm{HNO}_{3}$} \\
\hline 2 & -0.431 & 0.305 & 51.3 & 0.324 & 2.287 & 1.497 & $0.31-1.50$ \\
\hline 3 & -0.344 & 0.290 & 48.2 & 0.320 & 1.656 & 1498 & $0.32-1.50$ \\
\hline 5 & -0.390 & 0.336 & 50.3 & 0.499 & 2.309 & 1.571 & $0.49-1.57$ \\
\hline 6 & -0.375 & 0.320 & 52.0 & 0.541 & 2.772 & 1.540 & $0.54-1.54$ \\
\hline 7 & -0.361 & 0.433 & 56.5 & 0.475 & 3.420 & 1.558 & $0.47-1.56$ \\
\hline 11 & -0.412 & 0.408 & 66.4 & 0.549 & 3.864 & 1.539 & $0.54-1.53$ \\
\hline 15 & -0.368 & 0.339 & 49.3 & 0.476 & 2.373 & 1.497 & $0.47-1.50$ \\
\hline
\end{tabular}

The voltammograms obtained both in $4 \mathrm{M}$ and $0.4 \mathrm{M} \mathrm{HNO}_{3}$ solutions are similar for all the alloys studied an active domain being outstanding where the maximum current is $\mathrm{I}_{\mathrm{pc}}$, a passive domain, $\mathrm{D}_{\mathrm{pas}}$, characterized by a medium current of passivation, $\mathrm{I}_{\text {pas }}$, and at high values of the potential of $2.1 \mathrm{~V}$, in the transpassivation domain there appear oscillating currents with amplitudes higher in the more concentrated solution as can be seen in fig. 3 . In the solution 0.04 $\mathrm{M} \mathrm{HNO}_{3}$ the alloys behave differently, in the respect that the passive domain is no longer met, there exists a potential 
interval in which the current grows lineary. This is also illustrated in fig. 3 where the voltammograms plotted for sample 3 in the three solutions of $\mathrm{HNO}_{2}$ are shown.

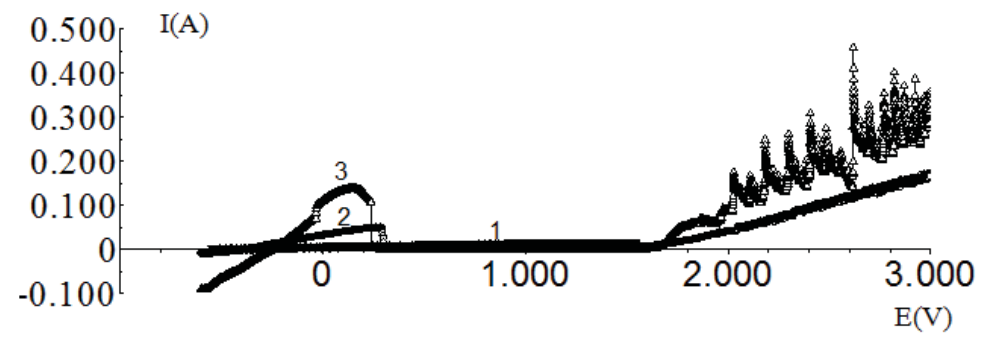

Fig. 3. The linear voltammograms obtained for sample 3 in solutions of different nitric acid concentrations at $\mathrm{v}=10 \mathrm{mV} / \mathrm{s}$; 1) $0.04 \mathrm{M}$; 2) $0.4 \mathrm{M}$; 3) $4 \mathrm{M}$

In table 4 , the values of the corrosion potential and the equations of the corrosion current dependency on the potential in its linear part are presented, where the linear correlation coefficient for all the alloy samples is 1.00 .

Some corrosion parameters obtained from the potentiodynamic method

Table 4

for steels immersed in $0.04 \mathrm{M} \mathrm{HNO}_{3}$ solution

\begin{tabular}{|c|c|c|c|}
\hline $\begin{array}{c}\text { Steel } \\
\text { sample }\end{array}$ & $\mathrm{E}_{\text {corr }}(\mathrm{V})$ & The liniar dependency domain $(\mathrm{V})$ & Equation: $\mathrm{I}(\mathrm{A})=\mathrm{f}(\mathrm{E})$ \\
\hline 2 & -0.504 & $-0.593-3.000$ & $4.758 \cdot 10^{-3}+9.812 \cdot 10^{-3} \mathrm{E}(\mathrm{V})$ \\
\hline 3 & -0.495 & $-0.389-0.989$ & $4.084 \cdot 10^{-3}+8.114 \cdot 10^{-3} \mathrm{E}(\mathrm{V})$ \\
\hline 5 & -0.456 & $-0.564-2.122$ & $4.077 \cdot 10^{-3}+9.30 \cdot 10^{-3} \mathrm{E}(\mathrm{V})$ \\
\hline 6 & -0.486 & $-0.570-2.498$ & $4.88 \cdot 10^{-3}+10.31 \cdot 10^{-3} \mathrm{E}(\mathrm{V})$ \\
\hline 7 & -0.479 & $-0.574-3.000$ & $4.219 \cdot 10^{-3}+10,22 \cdot 10^{-3} \mathrm{E}(\mathrm{V})$ \\
\hline 11 & -0.538 & $-0.599-3.000$ & $5.068 \cdot 10^{-3}+9.396 \cdot 10^{-3} \mathrm{E}(\mathrm{V})$ \\
\hline 15 & -0.475 & $-0.596-1.729$ & $5.316 \cdot 10^{-3}+11.42 \cdot 10^{-3} \mathrm{E}(\mathrm{V})$ \\
\hline
\end{tabular}

In fig. 4 along with the polarization curve obtained with immersing sample 5 in a solution of $0.4 \mathrm{M} \mathrm{HNO}_{3}$ (a), there is the curve obtained after $4 \mathrm{~h}$ (b) from the immersion, where one may notice a modification of the critical polarization current (from $50.3 \mathrm{~mA}$ decreases to $36.95 \mathrm{~mA}$ ) and the transfer of corresponding potential (from $0.336 \mathrm{~V}$ to $0.243 \mathrm{~V})$, as well as the current oscillations after $2.1 \mathrm{~V}$.

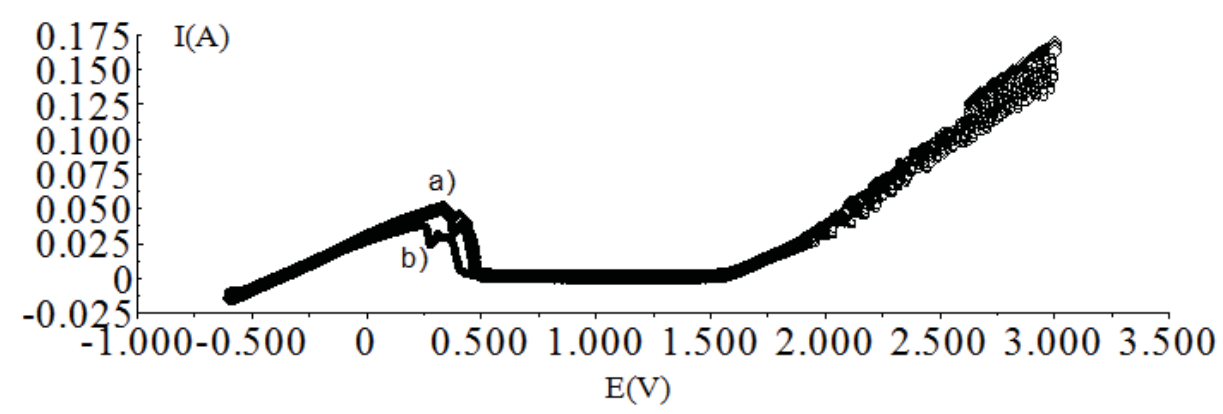

Fig. 4. The linear voltammograms obtained in $0.4 \mathrm{M} \mathrm{HNO}_{3}$ solution for sample 5 at $\mathrm{v}=10 \mathrm{mV} / \mathrm{s}$; a) initially; b) after 4 hours

In fig. 5 the in time modification of the polarization curve for sample 7 after being kept 18 hours in $0.04 \mathrm{M}$ $\mathrm{HNO}_{3}$, when the corrosion potential transfers to $-0.507 \mathrm{~V}$ (compared to $-0.479 \mathrm{~V}$ ) and the corrosion current dependency is given by the equation is shown:

$$
\mathrm{I}(\mathrm{A})=3.875 \cdot 10^{-3}+7.79 \cdot 10^{-3} \mathrm{E}(\mathrm{V}) \text { on the whole potential domain }(-0.6-3.0 \mathrm{~V})
$$




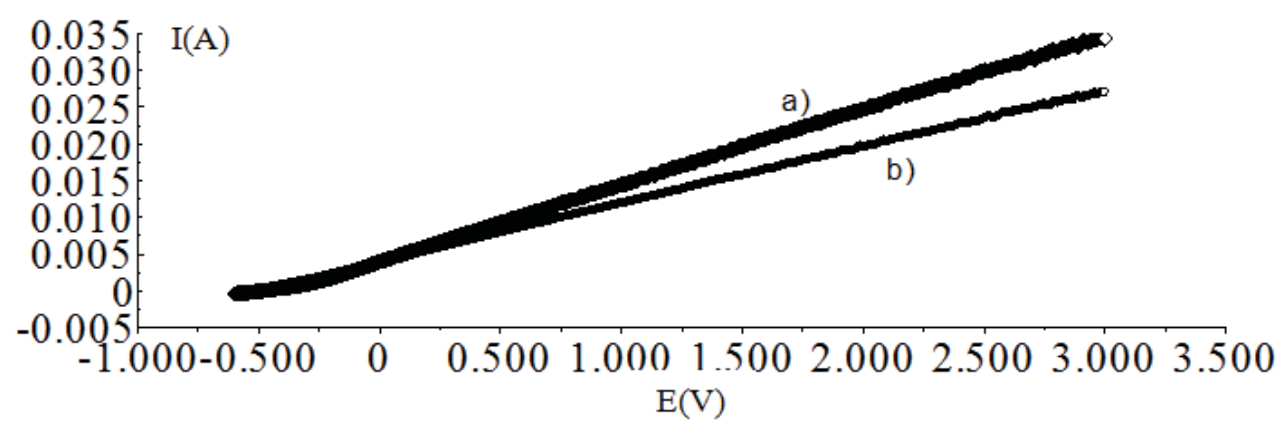

Fig. 5. The linear voltammograms obtained in $0.04 \mathrm{M} \mathrm{HNO}_{3}$ solution for sample 7 at v=10mV/s; a) initially, b) after 18 hours

Fig. 6 presents the linear voltammograms traced for sample 5 in $0.04 \mathrm{M} \mathrm{HNO}_{3}$ solution at certain immersion moments.

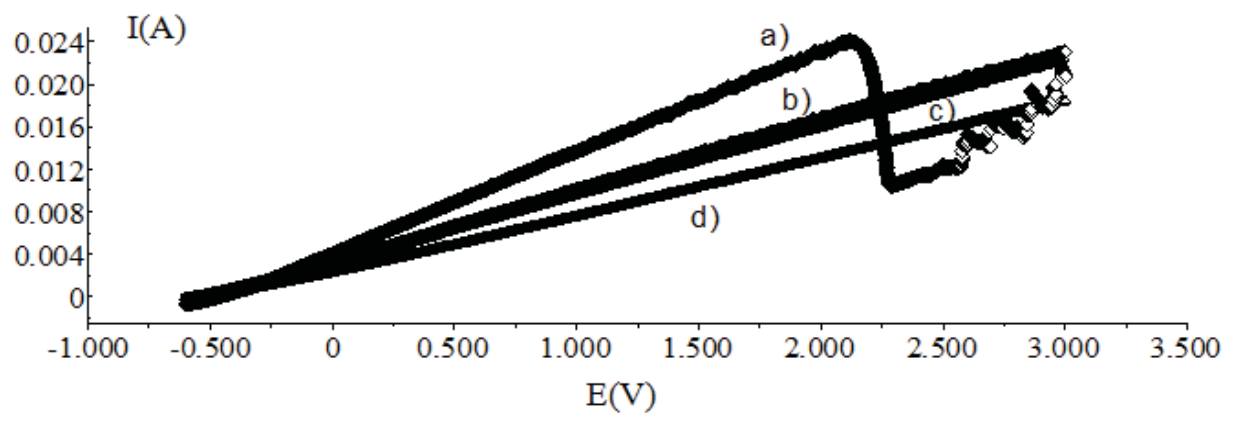

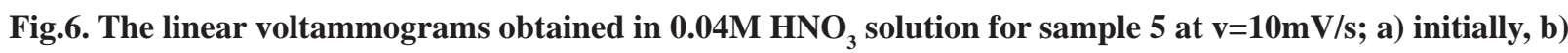
after 44 hours, c) after 74 hours, d) after 98 hours

In table 5 the corrosion potential and the dependency of the corrosion current on the potential applied for sample 5 in $0.04 \mathrm{M} \mathrm{HNO}_{3}$ at different immersion times are presented.

Table 5

Some corrosion parameters of sample 5 in a solution of $0.04 \mathrm{M} \mathrm{HNO}_{3}$ at different immersion times.

\begin{tabular}{|c|c|c|c|}
\hline Time from immersion (hours) & $\mathrm{E}_{\text {corr }}(\mathrm{V})$ & Potential domain $(\mathrm{V})$ & Equation $\mathrm{I}(\mathrm{A})=\mathrm{f}(\mathrm{E})$ \\
\hline 0 & -0.456 & $-0.564-2.122$ & $4.077 \cdot 10^{-3}+9.30 \cdot 10^{-3} \mathrm{E}(\mathrm{V})$ \\
\hline 44 & -0.525 & $-0.600-3.000$ & $3.226 \cdot 10^{-3}+6.539 \cdot 10^{-3} \mathrm{E}(\mathrm{V})$ \\
\hline 74 & -0.547 & $-0.599-3.000$ & $2.693 \cdot 10^{-3}+6.24 \cdot 10^{-3} \mathrm{E}(\mathrm{V})$ \\
\hline 98 & -0.564 & $-0.600-3.000$ & $2.353 \cdot 10^{-3}+5.237 \cdot 10^{-3} \mathrm{E}(\mathrm{V})$ \\
\hline
\end{tabular}

If the alloy sample immersion was done into the polarization curve at values higher than $2.10 \mathrm{~V}$ there appear current oscillations, which can be observed in table 5 after 44 hours for sample 5, or after 18 hours for sample 7 (fig. 5 ) .Here did not longer appear current oscillations, its dependency being linear up to $3.00 \mathrm{~V}$.

The electrochemical studies pointed out that the seven alloys considered are very close not only from the chemical composition, but also from the structural one, and the different microelements do not significantly change the voltammetric behavior. Yet, for given steels, it was noticed that the corrosion potential $\left(\mathrm{E}_{\mathrm{corr}}\right)$ is higher in the case if the aggressive medium of $\mathrm{HNO}_{3}$ has a lower concentration. This may be explained by the appearance of some iron oxide protection layers, which reduced the reaction rate on the steel surface undergoing corrosion, a fact that takes place faster when the $\mathrm{HNO}_{3}$ concentration is higher.

The data obtained in the present paper are added to those published ahead [38-39], referring to the behavior of iron alloys in aqueous solutions of nitric acid having different concentrations.

\section{Conclusions}

There are determined experimentally some electrochemical parameters such as; $\mathrm{R}_{\mathrm{p}}, \mathrm{E}_{\mathrm{corr}}, \mathrm{E}_{\mathrm{pc}}, \mathrm{I}_{\mathrm{pc}}, \mathrm{E}_{\mathrm{F}} \mathrm{I}_{\mathrm{pas}}, \mathrm{E}_{\mathrm{str}}$ and $\mathrm{D}_{\text {pas }}$, to characterize the corrosion process of seven steel samples immersed in different $\mathrm{HNO}_{3}$ solutions. Taking into 
account the obtained values from voltammetric studies it can pointed out the different behavior of steels, depending of experimental conditions. For more concentrated $\mathrm{HNO}_{3}$ solutions the corrosion process develops more slowly due to formation of some protected oxide layers on the steel surface immersed in the aggressive medium. There are presented some mathematical equations having the variables: $\mathrm{I}=\mathrm{f}(\mathrm{E})$ which described the steels behavior in the corrosion media.

\section{References}

[1]. Antropov, L.I., Teoreticescaia Elekrohimija, Visiaia Scolo, Moskva, 1984, p. 109.

[2]. Murgulescu, I.G., Radovici, O.M., Introduction in Physical Chemistry, vol.4, Electrochemistry, Romanian Acad. Ed., Bucharest, 1986, p. 361.

[3]. Oniciu, L., Metal Corrosion, Fundamental Aspects and Anticorrosion protection, Sci. Encicolop. Ed., Bucharest, 1986, p. 68.

[4]. Damaskin, B.B., Prakticum po elekrohimii, Visiaia Scola, Moskva, 1991, p.57.

[5]. Bockris, J.O’M.; Reddy, A.,Gambia-Adelco, M., Electrochemistry in Material Science, in: Modern Electrochemistry 2 B, Kluwer Academic/ Plenum Publ., New York, 1998, p. 1649.

[6]. Nemtoi, Gh., Electrochemistry - Fundamental Aspects, Tehnopress Ed., Iasi, 2011, p. 206.

[7]. Ahmad, Z., Principles of Corrosion Engineering and Control, Elsevier, Amsterdam, 2006, p.72.

[8]. Caceres, L., Vargas, T., Herrera, L., Corros.Sci., 49, 2007, p. 3168.

[9]. Singh, S.K., Mukherjee, A.K., J. Mater. Sci. Technol., 26, 2010, p. 268.

[10]. Sutiman, D., Cailean, A., Chiper, C., Nemtoi, Gh., Rev.Chim. (Bucharest), 54, 2003, p.579.

[11]. Mareci, D., Bocanu, C., Nemtoi, Gh., Aelenei, D., J. Serb. Chem. Soc., 70, 2005, p.891.

[12]. Gordin, D.M., Goriant, T., Nemtoi, Gh., Mat. Letters, 59, 2005, p.2959.

[13]. Nemtoi, Gh., Secula, M.S., Cretescu, Ig., Petrescu, S., Rev.Chim., (Bucharest), 57, 2007, p.952.

[14]. Nemtoi, Gh., Ionica, F., Lupascu, T., Cecal, A., Chem. J. Moldova, 5, 2010, p.98.

[15]. Moraru, M., Dumitrescu, V., Schiopescu, A., Negoiu, M., Rev. Chim. (Bucharest), 58, 2007, p.270.

[16]. Vogg, H., Braun, H., Loeffel, R., Lubecki, A., Merz, A., Schmitz, J., Schneider, J., Vehlow, J., J,Radioanal. Chem., 32, 1976, p.495.

[17]. Cecal, A., Stan, V., Z. Phys. Chem. (Leipzig), 263,1982, p.117.

[18]. Vehlow, J., KfK-Nachrichten, 15 ,1983, p.31.

[19]. Cecal, A., Electrochim. Acta, 28, 1983, p.681.

[20]. Cecal, A., Isotopenpraxis, 20, 1984, p.259.

[21]. Horany, G., Interface Science and Technology, vol.3., Elsevier B.V., Amsterdam, 2004, p.44.

[22]. Homonnay, Z., Szilagyi, P.A., Kuzmann, E., Varga, K., Nemeth, Z., Szabo, A., Rado, K., Schunk, J.; Tilky, P., Patek, G., J. Radioanal. Nucl. Chem., 273, 2007, p. 85

[23]. Sobkowski, J., INCS-News, 7, 2010, p.4.

[24]. Stern, M., Geary, A.L., J.Electrochem.Soc., 104, 1957, p.56.

[25]. Gileadi, E., Electrod Kinetics for Chemists, Verlag Chemie, Weinheim, 1993, p. 73.

[26]. Balbaud, F., Sanchez G., Fauvet, P., Santarini, G., Picard, P., Corros, Sci., 42, 2000, p.1685.

[27]. Armstrong, R.D., Cleland, G.E., J. Appl, Electrochem., 28, 1998, p. 1205.

[28]. Balbaud, F., Sanchez, G., Santarini, G., Picard, G., Eur. J. Inorg. Chem., 2, 1999, p. 277.

[29]. Kolman, D.G., Ford, D.K., Butt, D.P., Nelson, T.O., Corros. Sci., 39, 1997, p. 2067.

[30]. Sato, N., Corros., 45, 1989, p. 354.

[31]. Vertes, A.; Czako-Nagy, I. Electrochim. Acta, 34, 1989, p. 721.

[32]. Jones, D.A., Principles and Prevention of Corrosion, McMillan, New York, 1992, p.115.

[33]. Mansfeld, F., The polarisation resistance techniques for measuring of corrosion current, in Advances in Corrosion Science and Technology, 6, Plenum Press, New York, 1976, p.163.

[34]. Oniciu, L., Constantinescu, E., Electrochemistry and Corrosion, EDP, Bucharest, 1982, p.61.

[35]. Fontana, M.G., Corrosion Engineering, McGraw-Hill, New York, 1987, p.12.

[36]. Kasparova, O.V., Baldokhin, Y.V., Kochetov, G.A., Prot. Metals, 40, 2004, p. 425.

[37]. Ningshen, S., Kamachi Muladi, U., Amarendra, G., Raj, A., Corros Sci., 51, 2009, p. 322.

[38]. Cecal, A., Popa, K., Draghici, C., Radiochim.Acta, 93, 2005, p.115.

[39]. Cecal. A., Ionica, F.,Nemtoi, Gh., Popa, K., Rev.Roumaine Chim., 54, 2009, p.1127. 